\title{
A crystalline form of borcarite from the Fuka mine, Okayama Prefecture, Japan
}

\author{
Masayuki TAKADA ${ }^{*}$, Isao KUSACHI ${ }^{* *}$, Shigetomo KISHI ${ }^{* * *}$, \\ Mitsuo TANABE ${ }^{* * * * *}$ and Takashi YASUDA ${ }^{* * * * * *}$ \\ *452 Haikata, Oharano, Nishikyo-ku, Kyoto 610-1132, Japan \\ ** Department of Earth Sciences, Faculty of Education, Okayama University, \\ Tsushima-naka 3-1-1, Okayama 700-8530, Japan

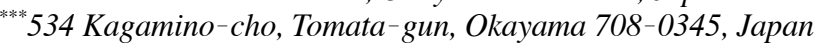 \\ ***** 2058-3 Niimi, Niimi, Okayama 718-0011, Japan \\ ******1471 Nishigata-cho, Ibara, Okayama 715-0015, Japan
}

\begin{abstract}
Euhedral crystals of borcarite were found in vugs or fissures of crystal aggregates of nifontovite or pentahydroborite, which occur as irregularly shaped bodies in the crystalline limestone near the gehlenite-spurrite skarns at the Fuka mine, Okayama Prefecture, Japan. Interfacial angles of the reference faces of borcarite crystals were measured for each zone using a one-circle goniometer. The crystal basically comprises the $\{110\},\{230\}$, $\{\overline{2} 01\},\{\overline{1} 24\}$ and $\{201\}$ faces, but some crystals also have the $\{100\},\{\overline{1} 02\},\{\overline{1} 01\},\{130\},\{140\},\{180\}$, $\{\overline{3} 11\}$ and $\{\overline{5} 11\}$ faces. Almost all the mineral is thin plate crystals along the zone [010]. The cleavage is perfect on $\{100\}$. Striation can be observed in the direction of [001]. This is the first description of a crystalline form of borcarite.
\end{abstract}

Keywords: Crystal form, Borcarite, Skarn, Fuka mine, Japan

\section{INTRODUCTION}

Takada et al. (2005) first reported the crystal forms of borate minerals such as frolovite, henmilite, olshanskyite, pentahydroborite, hexahydroborite, nifontovite and uralborite from the Fuka mine, Okayama Prefecture, Japan. Borcarite is another borate mineral with an ideal formula of $\mathrm{Ca}_{4} \mathrm{MgB}_{4} \mathrm{O}_{6}(\mathrm{OH})_{6}\left(\mathrm{CO}_{3}\right)_{2}$. The mineral was originally found in Siberia on a dolomite marble in contact with granodiorite (Pertsev et al., 1965). Later, Malinko et al. (1978) found the mineral at the Solongo contact-metasomatic deposit in Buryat and later Kusachi et al. (1997) found it in the crystalline limestone near the gehlenitespurrite skarns at the Fuka mine. Although borcarites from the three localities above occur as euhedral crystals, the crystal form has not yet been revealed. During a mineralogical survey of the skarns at the Fuka mine, euhedral crystals of borcarite, for which the interfacial angles between the crystal faces were measurable, were found at the mine. This paper reports the crystal form of borcarite for the first time.

doi: $10.2465 /$ jmps.060222

M. Takada,pegma@mbox.kyoto-inet.or.jp

I. Kusachi, kusachi@cc.okayama-u.ac.jp Corresponding author

\section{OCCURRENCE}

Borate minerals, mainly nifontovite and pentahydroborite, occur in large quantities in an irregularly shaped body, which is about $3 \mathrm{~m}$ wide and about $7 \mathrm{~m}$ long, in the crystalline limestone near the gehlenite-spurrite skarns at the Fuka mine. Accessory constituents are other borate minerals, such as frolovite, sibirskite, parasibirskite, uralborite, hexahydroborite and inyoite (Kusachi et al., 2004). A calcite vein runs through the irregularly shaped body. The vein contains henmilite, ettringite group minerals, cuspidine, cahnite and so on.

Borcarite is present as an accessory constituent in vugs or fissures of crystal aggregates of nifontovite or pentahydroborite. Borcarite is either achromatic or pale green, and is frequently accompanied by blue-green numanoite (Ohnishi et al., 2005) at the center of the crystals up to $5 \mathrm{~mm}$ in length. The mineral assemblage containing borcarite is different from that reported by Kusachi et al. (1997), who found it in association with olshanskyite, bultfonteinite and calcite. Figure 1 shows the occurrence of the present borcarite. 


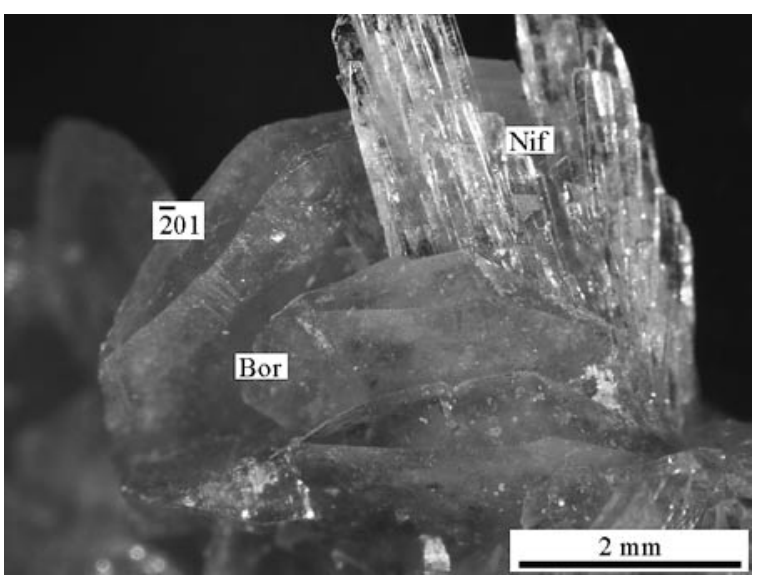

Figure 1. Thin plate crystals of borcarite from the Fuka mine. The $\{\overline{2} 01\}$ face is characteristically observed. Abbreviations: Bor, borcarite; Nif, nifontovite.

\section{MEASUREMENT METHOD}

The crystal form was examined using a method reported by Takada et al. (2005). The plane index of each crystal face and zone axis for each zone were determined by the following procedures: 1) interfacial angles with the reference faces were measured for each zone using a one-circle goniometer; 2) the angles between two kinds of faces with various plane indices were determined by calculation for each zone from the mineral cell parameters; then 3) both the plane index of each crystal face and zone axis [uvw] were determined simultaneously, with the difference between the measured and calculated values within \pm 2.0 degrees.

\section{CRYSTAL FORM}

Three crystals, each with diameters of 2-3 mm, were used for the measurements. Table 1 shows the measured and calculated values of the interfacial angles (mean values and standard deviation), zone axes and crystal plane indices. In zones [103] and [105], the $\{010\}$ face is not present so the $\{180\}$ face was used instead as the reference face for measurement. The calculated values were determined from the cell parameters of the mineral: $a=17.82$, $b=8.382, c=4.452 \AA$ and $\beta=101.95^{\circ}$ (Kusachi et al., 1997). The difference between the measured and calculated values is within \pm 1.7 degrees.

Figures 2 (a) and 2 (b) show the crystal forms consisting of main faces of borcarite from the Fuka mine, and 2 (c) shows the crystal form in the case where all crystal faces are present. Figures 2 (d) and (e) show the forms of 2 (c) viewed from the $c^{-}$and $b$-axes, respectively. The borcarite crystal basically comprises the $\{110\},\{230\}$, $\{\overline{2} 01\},\{\overline{1} 24\}$ and $\{201\}$ faces as shown in Figure 2 (a),
Table 1. Interfacial angles measured for borcarite from the Fuka mine

\begin{tabular}{|c|c|c|c|}
\hline h k & & Measured ( $\left.{ }^{\circ}\right)$ & Calcurated $\left({ }^{\circ}\right)^{* *}$ \\
\hline & & \multicolumn{2}{|c|}{ [ $\left.\begin{array}{lll}0 & 0 & 1\end{array}\right]$ zone } \\
\hline$\bigcirc 10$ & 0 & 0.0 & 0.00 \\
\hline 11 & 0 & $63.4 \pm 1.0$ & 64.32 \\
\hline 34 & 0 & 70.0 & 70.17 \\
\hline 23 & 0 & $71.6 \pm 0.4$ & 72.23 \\
\hline 12 & 0 & 77.0 & 76.48 \\
\hline 13 & 0 & $80.3 \pm 0.5$ & 80.90 \\
\hline 14 & 0 & $83.0 \pm 0.4$ & 83.15 \\
\hline \multirow[t]{2}{*}{18} & 0 & $86.7 \pm 0.6$ & 86.56 \\
\hline & & \multicolumn{2}{|c|}{$\left[\begin{array}{lll}0 & 1 & 0\end{array}\right]$ zone } \\
\hline$\bigcirc 10$ & 0 & 0.0 & 0.00 \\
\hline * 20 & 1 & $55.9 \pm 1.0$ & 54.17 \\
\hline$* \overline{1} 0$ & 2 & $84.3 \pm 0.4$ & 85.20 \\
\hline$* \overline{1} 0$ & 1 & $93.3 \pm 0.4$ & 92.50 \\
\hline$* \overline{2} 0$ & 1 & $105.6 \pm 1.3$ & 106.64 \\
\hline \multirow[t]{2}{*}{10} & 0 & $179.9 \pm 1.4$ & 180.00 \\
\hline & & \multicolumn{2}{|c|}{$\left[\begin{array}{lll}1 & \overline{1} & 2\end{array}\right]$ zone } \\
\hline$\bigcirc 11$ & $\underline{0}$ & 0.0 & 0.00 \\
\hline 31 & $\overline{1}$ & $55.5 \pm 0.5$ & 55.25 \\
\hline \multirow[t]{2}{*}{$* 2$} & $\overline{1}$ & $83.8 \pm 0.8$ & 82.87 \\
\hline & & \multicolumn{2}{|c|}{$[1 \overline{1} 4]$ zone } \\
\hline$\bigcirc 11$ & 0 & 0.0 & 0.00 \\
\hline 51 & $\overline{1}$ & $53.5 \pm 0.7$ & 52.79 \\
\hline$\underline{3} \overline{1}$ & $\overline{1}$ & $100.0 \pm 1.4$ & 100.90 \\
\hline \multirow[t]{2}{*}{$\overline{1} \overline{1}$} & 0 & $179.5 \pm 0.7$ & 180.00 \\
\hline & & \multicolumn{2}{|c|}{$\sim\left[\begin{array}{lll}1 & 0 & 3\end{array}\right]$ zone } \\
\hline$\bigcirc 18$ & 0 & 0.0 & 0.00 \\
\hline 31 & $\overline{1}$ & $63.8 \pm 0.4$ & 63.46 \\
\hline $3 \underline{1}$ & 1 & $112.3 \pm 0.4$ & 113.21 \\
\hline \multirow[t]{2}{*}{$1 \overline{8}$} & 0 & $174.5 \pm 0.7$ & 173.12 \\
\hline & & \multicolumn{2}{|c|}{$\sim\left[\begin{array}{lll}1 & 0 & 5\end{array}\right]$ zone } \\
\hline$\bigcirc 18$ & $\underline{0}$ & 0.0 & 0.00 \\
\hline $5 \underline{1}$. & $\overline{1}$ & $66.8 \pm 1.1$ & 67.54 \\
\hline $5 \underline{1}$ & $\overline{1}$ & $106.3 \pm 0.4$ & 107.45 \\
\hline $1 \overline{8}$ & 0 & $172.8 \pm 1.1$ & 173.12 \\
\hline
\end{tabular}

but some crystals also have the $\{100\},\{\overline{102}\},\{101\}$, $\{130\},\{140\},\{180\},\{\overline{3} 11\}$ and $\{\overline{5} 11\}$ faces, as shown in Figures 2 (b) and (c). The $\{120\}$ and $\{340\}$ faces are not shown in Figure 2, because they were observed only at one point. Among the crystal faces, there are curved faces in zones [010] and [11 2$]$, particularly the $\{\overline{1} 02\}$ and $\{\overline{101}\}$ faces. The pyramidal face $\{\overline{1} 24\}$ is also curved but relatively large and conspicuous. Since the pyramidal face does not form any zone axis with three or more crystal faces, the plane index was determined by measuring the interfacial angle with the basic crystal face. For these curved faces, the angles were determined at the center of faces. The cleavage is perfect on $\{100\}$. Striation can be observed in the direction of [001], particularly the prismatic faces. Consequently, many small prismatic faces 
(a)

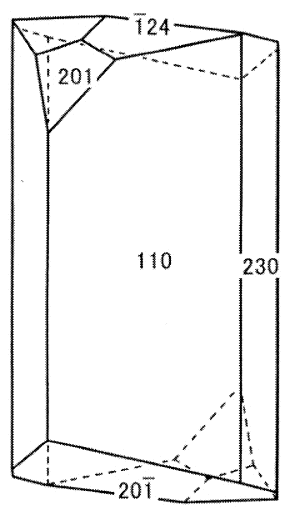

(d)

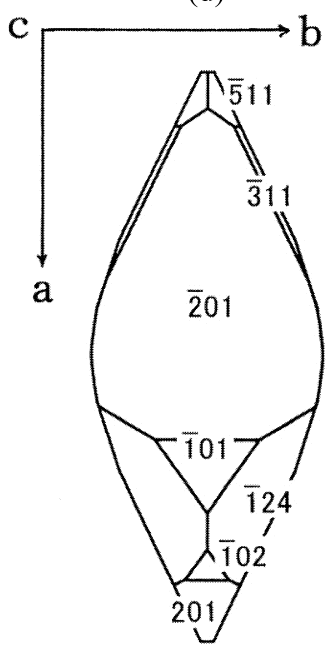

(b)

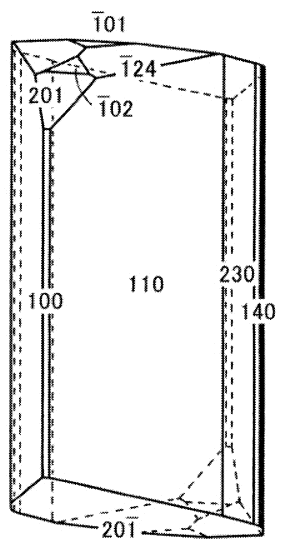

(c)

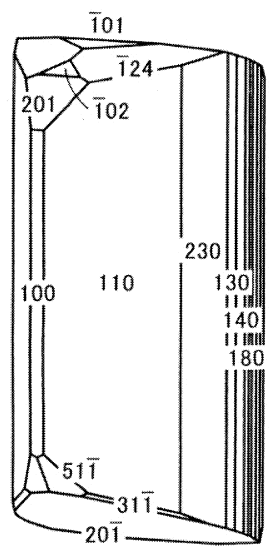

(e)

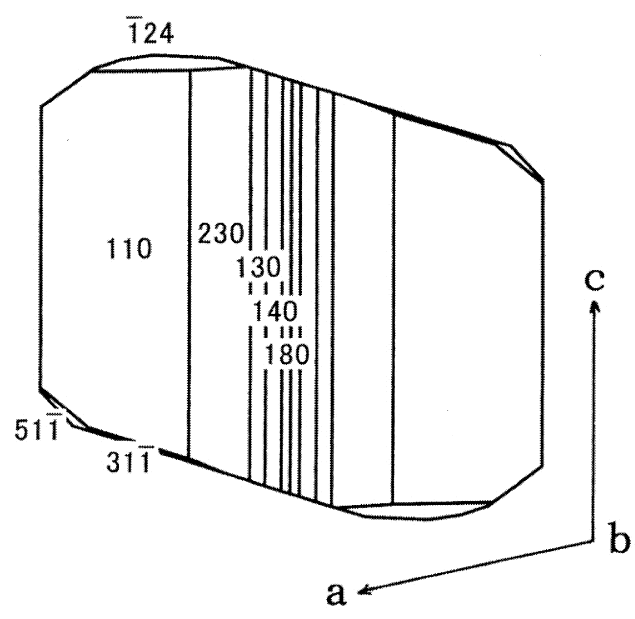

Figure 2. Crystal forms of borcarite from the Fuka mine. Monoclinic, $2 / \mathrm{m}$, axial ratio $a: b: c=2.126: 1: 0.531, \beta=101.95^{\circ}$ (Kusachi et al., 1997).

(a) and (b), forms of the measured crystals consisted of main faces; (c), form where all the crystal faces are present; (d) and (e), forms of (c) viewed from the $c^{-}$and $b$-axes.

such as $\{130\},\{140\}$ and $\{180\}$ are present. The $\{311\}$ and $\{\overline{5} 11\}$ faces are also small, but can be viewed clearly. These faces form various zone axes with other crystal faces, and the measured and calculated values thereof are shown in Table 1. Almost all the mineral is thin plate crystals along the zone [010], as shown in Figures 1 and 2. In Figure 1, the characteristic $\{\overline{2} 01\}$ face is observed.

\section{SUMMARY}

Interfacial angles of the reference faces of borcarite crystals from the Fuka mine, Okayama Prefecture, Japan, were measured for each zone using a one-circle goniometer. The borcarite crystal basically comprises the $\{110\}$, $\{230\},\{\overline{2} 01\},\{\overline{1} 24\}$ and $\{201\}$ faces, but some crystals also have the $\{100\},\{\overline{1} 02\},\{101\},\{130\},\{140\},\{180\}$, $\{\overline{3} 11\}$ and $\{\overline{5} 11\}$ faces. Almost all the mineral is thin plate crystals along the zone [010]. The cleavage is perfect on $\{100\}$. Striation can be observed in the direction of [001].

\section{ACKNOWLEDGMENTS}

We would like to sincerely thank Bihoku Funka Kogyo Co., Ltd. and Mr. K. Shimada for carrying out the fieldwork. Thanks are also due to Dr. S. Matsubara and an anonymous reviewer.

\section{REFERENCES}

Kusachi, I., Kobayashi, S., Tanabe, M., Kishi, S. and Yamakawa, J. (2004) Inyoite from Fuka, Okayama Prefecture, Japan. Journal of Mineralogical and Petrological Sciences, 99, 6771. 
Kusachi, I., Takechi, Y., Henmi, C. and Kobayashi, S. (1997) Borcarite from Fuka, Okayama Prefecture, Japan. Mineralogical Journal, 19, 115-122.

Malinko, S.V., Kuznetsova, N.N. and Yurkina, K.V. (1978) Borcarite from Solongo, its parageneses, composition and properties. Doklady Akademii Nauk SSSR, 26, 94-104 (in Russian).

Ohnishi, M., Kusachi, I., Kobayashi, S., Yamakawa, J., Tanabe, M., Kishi, S. and Yasuda, T. (2005) $\mathrm{Cu}^{-}$analogue of borcarite from the Fuka mine, Takahashi, Okayama Prefecture, Japan. Annual Meeting Abstracts of the Mineralogical Society of Japan, 138 (in Japanese).

Pertsev, N.N., Ostravskaya, I.V. and Nikitina, I.B. (1965) The new mineral borcarite. Zapiski Vserossiũskoga Mineralogicheskoga Obshchestva, 94, 180-186 (in Russian).
Takada, M., Kusachi, I., Kishi, S., Tanabe, M. and Yasuda, T. (2005) Crystal forms of borate minerals from the Fuka mine, Okayama Prefecture, Japan. Japanese Magazine of Mineralogical and Petrological Sciences, 34, 252-260 (in Japanese with English abstract).

Color version of Figure 1 is linked to the online version of the paper at http://www.jstage.jst.go.jp/browse/jmps

Manuscript received February 22, 2006

Manuscript accepted June 1, 2006

Published online November 24, 2006

Manuscript handled by Yasuhiro Kudoh 